\title{
Feeding of a pelagic chaetognath, Sagitta friderici Ritter-Záhony off Ubatuba region (São Paulo, Brazil)
}

\author{
Luz Amelia VEGA-PÉREZ \& LIANG, Tsui Hua \\ Instituto Oceanográfico da Universidade de São Paulo \\ (Caixa Postal 9075, 01065-970 São Paulo, SP, Brasil)
}

- Abstract: The diet of Sagitta friderici off Ubatuba region, São Paulo State, was studied in March, 1989. Specimens were collected with a closing-net during three days at six hours' intervals $(00: 00 ; 06: 00 ; 12: 00 ; 18: 00 \mathrm{~h})$, at a fixed station of $38 \mathrm{~m}$ depth. The population was composed basically by young stages (O-II). A total of 3175 specimens were examined but only 760 contained preys in their guts. Copepods were the main constituent of food eaten $(79.86 \%)$. There was a preference for the genera Paracalanus, Oncaea, Corycaeus and for crustacean nauplii. Other zooplanktonic groups such as Annelida, Urochordatha, and Mollusca were also found in the gut. Cannibalistic behavior occurred in $2.66 \%$ of the samples. In $S$. friderici the food was selected by size and was a direct function of the predator size. Younger stages (O-I) selected small prey, whereas older stages (II) preferred larger preys. Specimens collected above the thermocline exhibited higher feeding intensity (FCR) during the night periods.

- Descriptors: Feeding, Predation, Zooplankton, Chaetognatha, Sagitta friderici, Ubatuba, Brazil.

- Descritores: Alimentação, Predação, Zooplâncton, Chaetognatha, Sagitta friderici, Ubatuba: SP, Brasil.

\section{Introduction}

Chaetognaths constitute a substantial fraction of the macroplankton (Reeve \& Walter, 1972). They are considered primary carnivorous and key food species for commercial fishes (Heydorn, 1959).

The studies of their feeding habits have shown that chaetognaths are probably one of the main predation pressures on the copepod community (Alvariño, 1985; Oresland, 1987).

Sagitta friderici Ritter-Záhony (1911) is described as a neritic, epiplanktonic chaetognath, preferring lower salinity water, but also able to tolerate oceanic salinities and temperatures between $13^{\circ}-27^{\circ} \mathrm{C}$ (Furnestin, 1957; McLelland, 1980, 1989). It is a common member of the plankton from coastal waters of the Ubatuba region, where it is numerically dominant during the year. However, little is known about its feeding habits.

The objective of the investigation described below is to study the diet composition of $S$. friderici and determine the existence of selective feeding.

Contr. no. 735 do Inst. oceanogr. da Usp.

\section{Material and methods}

Zooplankton samples were collected off the Ubatuba region $\left(23^{\circ} 35^{\circ} \mathrm{S} ; 4^{\circ} 49^{\circ} \mathrm{W}\right)$, São Paulo during March 6-8, 1989 at a fixed station over $38 \mathrm{~m}$ depth. Vertical tows above $(5-0 \mathrm{~m})$ and below $(35-10 \mathrm{~m})$ the thermocline were made with a closing-net $(0.5 \mathrm{~m}$ mouth diameter and $0.200 \mathrm{~mm}$ mesh aperture), every six hours (00:00; 06:00; $12: 00 ; 18: 00$ ) during three days. Temperature and salinity data of the water column were obtained simultaneously with Nansen bottles.

The zooplankton samples were preserved with $10 \%$ buffered formalin solution.

In the laboratory, 3175 specimens of Sagitta friderici were removed from the samples and their gut contents analyzed by body transparency. The position of the food in the gut was recorded and only the preys localized at posterior region were considered.

The food items were identified as much as possible in species using a Wild M8 stereo microscope. The taxonomy of the copepods prey was based on Björnberg (1981) and chaetognath maturity stages were determined according to Reeve (1970): O-II, young stages; III-IV, adult stages. 
Finally, food containing ratio (FCR), i.e., number of chaetognaths containing food/total number $\mathrm{ci}$ chaetognaths X 100, was calculated.

\section{Results}

Sagitta friderici was the most abundant species in Ubatuba region in March, 1989. Their numbers varied from one sample to another suggesting mobility and dispersion of the population. They occurred both above and below the thermocline with a tendency to agregate in lower layers, where the temperature was cooler $\left(15.5^{\circ} \mathrm{C}\right)$ than at the surface $\left(26.5^{\circ} \mathrm{C}\right)$.
The population was composed of juvenile stages. Approximately $97.73 \%$ of the specimens taken during the different periods of the day were juveniles and $2.27 \%$ adults (Table 1).

Analysis of the gut contents of $3175 \mathrm{~S}$. friderici showed that 2415 specimens had empty guts and 760 contained food ( 771 prey items). The guts generally had one prey, but 2-3 items were found in eight specimens. In all cases this species swallowed its prey whole.

The diet was composed basically of Crustacea (88.52\%), Annelida (4.71\%), Urochordatha (3.69\%), Chaetognatha (2.66\%) and Mollusca (0.41\%) (Fig. 1). The specific composition is presented in Table 2 . Generally, the diet was composed of a high diversity of items, 28 , but in low numbers. The diversity varied with maturity stage of $S$. friderici. In stage I, for example, 25 items were

Table 1. Number, percentage of different stages and food containing ratio of Sagitta friderici at the different maturity stages

\begin{tabular}{|c|c|c|c|c|c|c|}
\hline 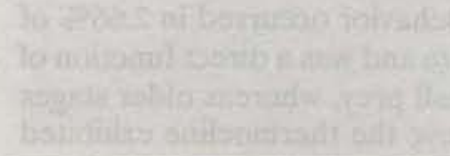 & 0 & $\begin{array}{c}\text { Young } \\
\text { I }\end{array}$ & $\begin{array}{l}\text { Maturity } \\
\text { II }\end{array}$ & Stages & $\begin{array}{l}\text { Adult } \\
\text { IV }\end{array}$ & Total \\
\hline$N^{2}$ of $S$. friderici examined & 1857 & 956 & 290 & 65 & 7 & 3175 \\
\hline Percentage & 58.49 & 30.11 & 9.13 & 2.05 & 0.22 & 100 \\
\hline$N^{2}$ of specimens with food & 245 & 420 & 93 & 2 & - & 760 \\
\hline Food containing ratio & 13.19 & 43.93 & 32.07 & 3.07 & - & 23.94 \\
\hline
\end{tabular}

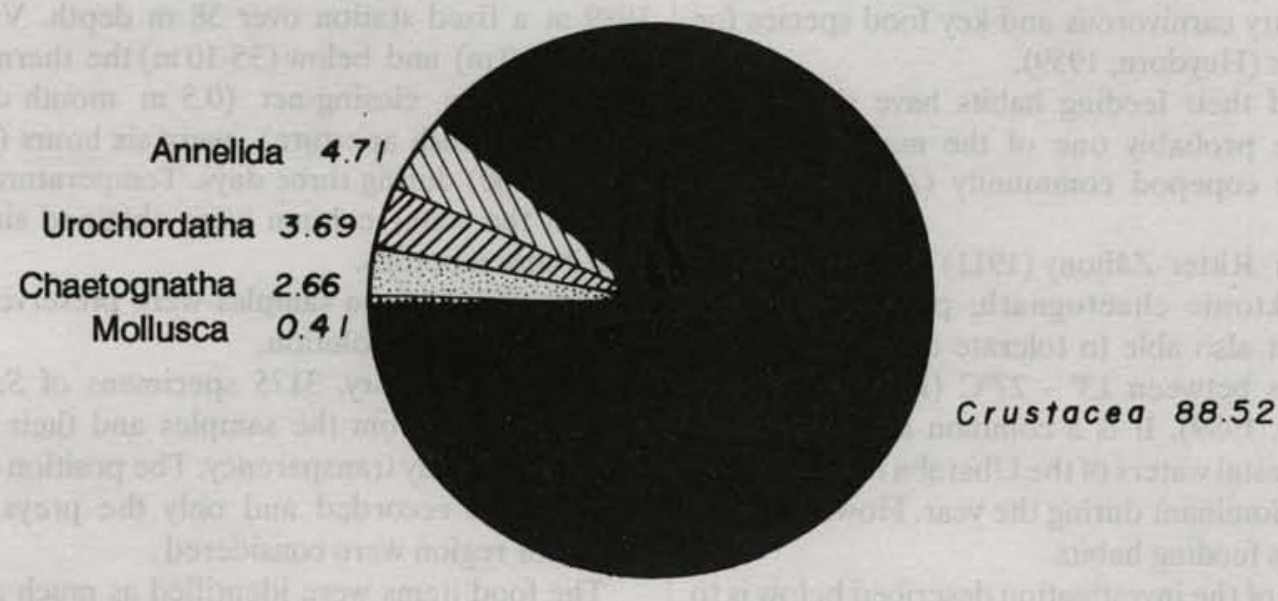

Fig. 1. Percentage of food categories found in the guts of Sagitta friderici. 
Table 2. The specific composition of the diet of Sagitta friderici at different maturity stages

\begin{tabular}{|c|c|c|c|c|c|}
\hline \multirow[b]{2}{*}{ Food } & \multicolumn{2}{|c|}{$\begin{array}{l}\text { Maturit } \\
\text { Young }\end{array}$} & \multicolumn{2}{|c|}{$\begin{array}{l}\text { Stages } \\
\text { Adul ts }\end{array}$} & \multirow[b]{2}{*}{ Total } \\
\hline & item & 1 & II & 111 & \\
\hline \multicolumn{2}{|c|}{$\begin{array}{l}\text { Crustacea } \\
\text { Copepoda }\end{array}$} & \multicolumn{4}{|c|}{$\begin{array}{l}\text { AP } \\
\text { ant }\end{array}$} \\
\hline \multicolumn{4}{|c|}{ Calanoida } & & \\
\hline \multicolumn{2}{|r|}{ Nannocalanus minor } & 3 & \multicolumn{2}{|l|}{3} & 6 \\
\hline \multirow{2}{*}{\multicolumn{2}{|c|}{$\begin{array}{l}\text { Paracalanus sp } \\
\text { P. quasimodo }\end{array}$}} & 28 & \multirow{2}{*}{\multicolumn{2}{|c|}{3}} & 44 \\
\hline & & 15 & & & 19 \\
\hline \multicolumn{2}{|r|}{ P. crassirostris } & 1 & & & 1 \\
\hline \multirow{2}{*}{\multicolumn{2}{|c|}{$\begin{array}{l}\text { Clausocalanus furcatus } \\
\text { Ctenocalanus }\end{array}$}} & 12 & & & 12 \\
\hline & & 11 & & & 16 \\
\hline \multicolumn{2}{|r|}{ Arcatia lilljeborgi } & 3 & 1 & & 4 \\
\hline \multicolumn{2}{|r|}{ Temora stylifera } & 17 & 7 & & 27 \\
\hline \multirow{2}{*}{\multicolumn{2}{|c|}{$\begin{array}{l}\text { Centropages velificatus } \\
\text { Pontellopsis sp }\end{array}$}} & & 1 & & 1 \\
\hline & & 1 & 1 & & 2 \\
\hline \multicolumn{2}{|r|}{ Pontellopsis sp } & leans $=$ & 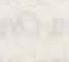 & $x^{2}$ & phes \\
\hline \multicolumn{2}{|r|}{ Corycaeus sp } & 9 & 1 & & 11 \\
\hline \multicolumn{2}{|r|}{ Corycaeus speciosus } & 9 & 2 & & 11 \\
\hline \multicolumn{2}{|r|}{ C. amazonicus } & 2 & & & 2 \\
\hline \multirow{2}{*}{\multicolumn{2}{|c|}{$\begin{array}{l}\text { C. giesbrechti } \\
\text { Furanula sp }\end{array}$}} & 10 & 3 & & 17 \\
\hline Farranula sp & & 1 & 5 & det & 1 \\
\hline & Oncaea spp & 34 & 5 & & 60 \\
\hline \multicolumn{2}{|r|}{ Oithona plumifera } & 1 & $x^{3} x^{2}$ & & 1 \\
\hline \multicolumn{6}{|c|}{ Harpacticoida } \\
\hline \multirow{2}{*}{\multicolumn{2}{|c|}{$\begin{array}{l}\text { Microsetella norvegica } \\
\text { Macrosetella gracilis }\end{array}$}} & 5 & & & 7 \\
\hline & & & 1 & & 1 \\
\hline & Euterpina acutifrons & 4 & & & 5 \\
\hline & ident if ied copepods & 50 & 17 & 1 & 97 \\
\hline & adocera & 7 & & & 13 \\
\hline & Evadne sp & 1 & 2 & & $\begin{array}{r}15 \\
3\end{array}$ \\
\hline & ustacean nauplii & 16 & 1 & & 71 \\
\hline & nel ida (larvae) & 11 & & & 23 \\
\hline & llusca & & & & 2 \\
\hline & ochordatha & & & & \\
\hline & Oikopleura spp & 9 & 8 & & 18 \\
\hline & aetognatha & & & & \\
\hline & $S$. friderici & 6 & 6 & & 12 \\
\hline & S. tenuis & 1 & & & 1 \\
\hline & identified prey & 161 & 33 & 1 & 283 \\
\hline & Total prey items & 428 & 95 & 2 & 771 \\
\hline
\end{tabular}


identified, whereas stage $\mathrm{O}$ and II showed 14 and 15 items, respectively. We also observed higher diversity of food items in specimens collected below the thermocline than above it.

The most important prey within the global diet were the copepods, specially Calanoida (40.29\%), Cyclopoida $(29.85 \%)$ and Harpacticoida $(3.77 \%)$. The percentage of unidentified copepods was $26.08 \%$ (Fig. 2). In all stages the genera Paracalanus, Oncaea and Corycaeus were the most frequent and significant food items (Fig. 3A-C). Crustacean nauplii were also important food, specially for stage $\mathrm{O}$ (Fig. 3A). Appendicularians and Annelida larvae were other important preys of $S$. friderici. Predation on chaetognaths were detected in stage $I(2.62 \%)$ and it tended to increase during stage II (9.68\%) (Fig. 3 $\mathrm{B}, \mathrm{C})$.

The percentage of unidentified prey present in the gut of $S$. friderici, during this study was very high (36.70\%).

The diet of stage III was not studied here, because only two individuals contained food in their gut. All specimens of stage IV showed an empty gut.

In $S$. friderici prey size changed with the developmental stages. Younger stages (O-I) preferred nauplii and small-sized copepod of the genera Oncaea and Paracalanus, whereas older stages took larger preys such as Temora stylifera and Corycaeus spp (Fig. 3C).

The food containing ratio (FCR) showed that the number of guts with prey was higher in specimens collected at night. The period of more intensive feeding was recorded at 18:00-00:00 $\mathrm{h}$ in the first day and at 00:00-06:00 $\mathrm{h}$ during the second day of sampling. In all cases the time of maximum intensity was not the same (Fig.
4). The diel trends in feeding were more evident in specimens collected above the thermocline than below it.

\section{Discussion}

During March, 1989 Ubatuba was dominated by numerous young stages (O-II) of $S$. friderici. Almeida-Prado (1968) also found a dominance of juvenile stages in the Cananéia and Santos regions. She suggested that adult scarcity was due to near-shore sampling and the distribution of the chaetognaths in the deeper layers. Recently, Stuart \& Verheye (1991) found more adults than juveniles of $S$. friderici off the west coast of South Africa, in $70 \mathrm{~m}$ deep collections.

Temperature is one of the factors which appear to influence the distribution of $S$. friderici. Almeida-Prado (1961) recorded a large temperature range for this species $\left(13^{\circ} \mathrm{C}-27^{\circ} \mathrm{C}\right)$, but according to Heydorn (1959) the species never occurs in large numbers when the temperature of the water is higher than $13^{\circ} \mathrm{C}$. $S$. friderici from Ubatuba region was more abundant below the thermocline, where the temperature was $15.5^{\circ} \mathrm{C}$. Our results confirm the preference of this species for the lower temperature.

$S$. friderici was found to have a pattern of feeding habits similar to previously reported studies on other chaetognaths. Copepods were the main constituent of food eaten, representing $79.86 \%$ of their diet. It showed preference by copepods of the genera Paracalanus and Oncaea. This result confirms Stone (1969) and Pearre

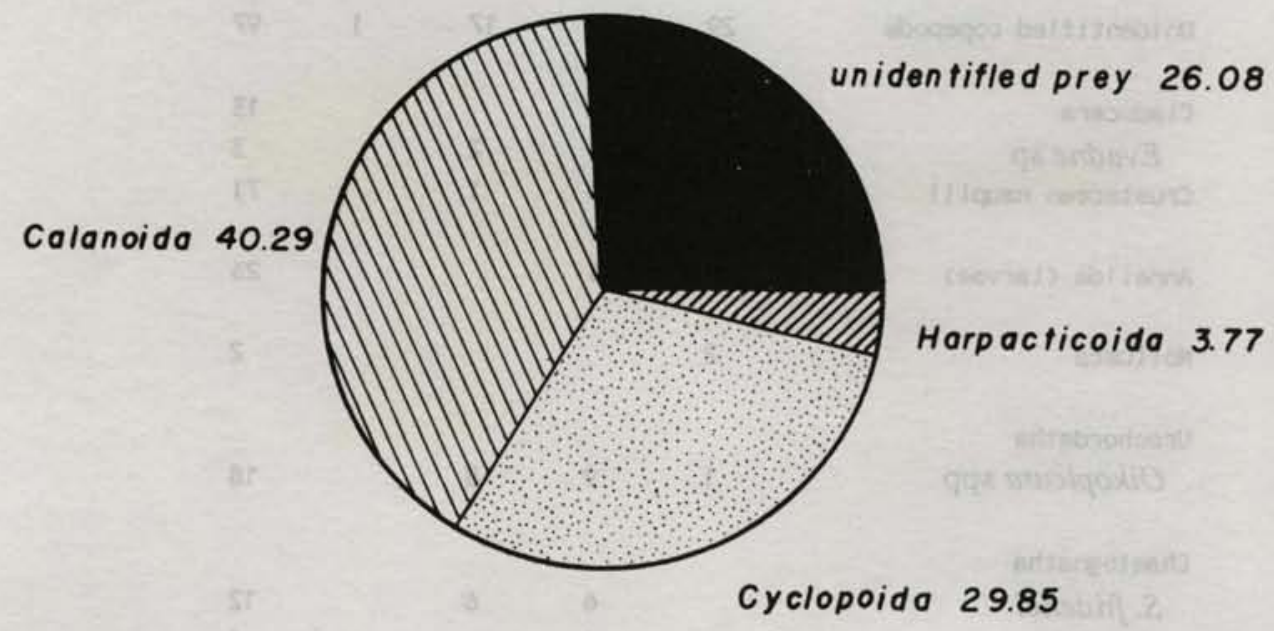

Fig. 2. Percentage of copepods found in the gut of Sagitta friderici. 

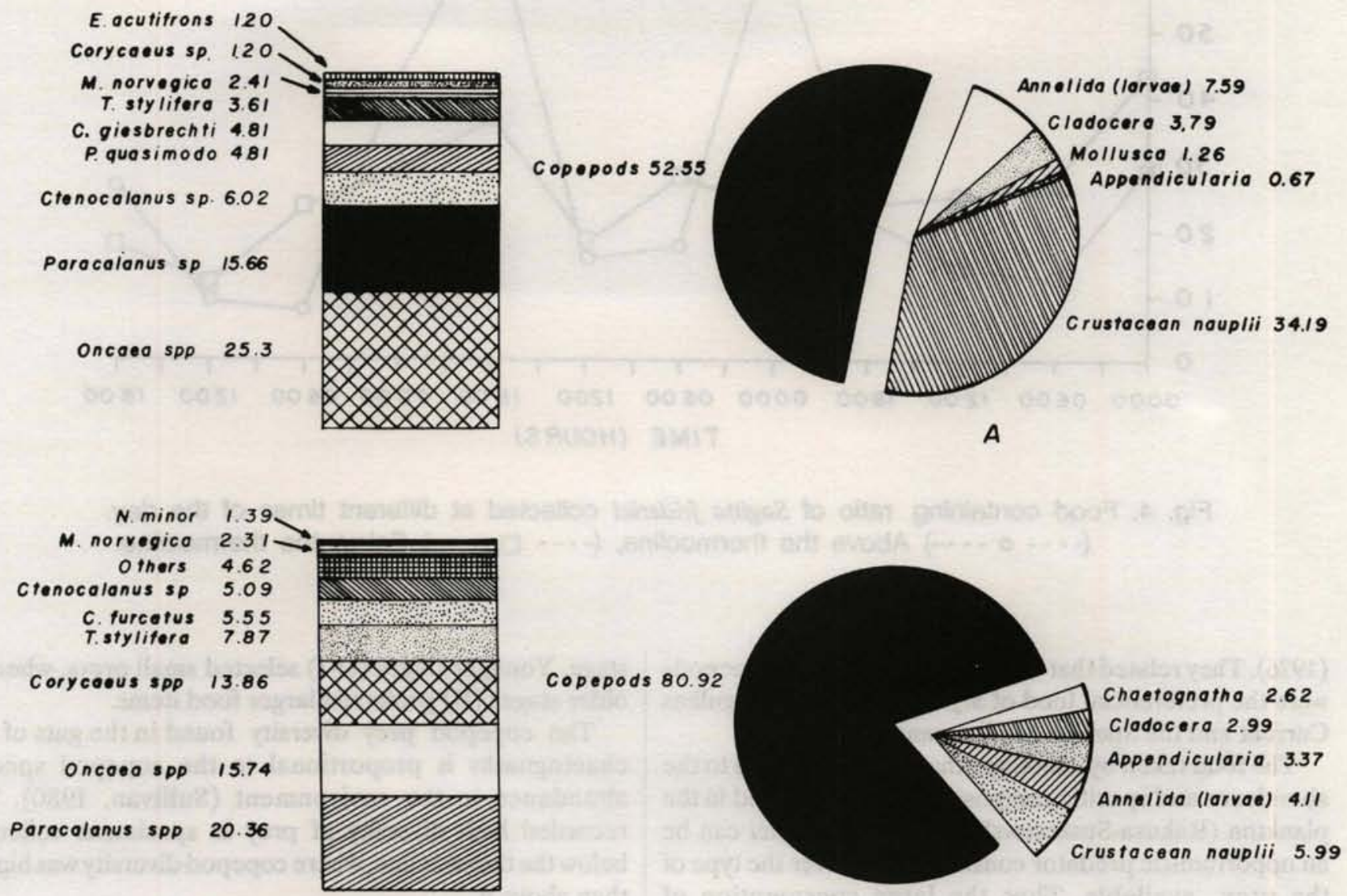

B
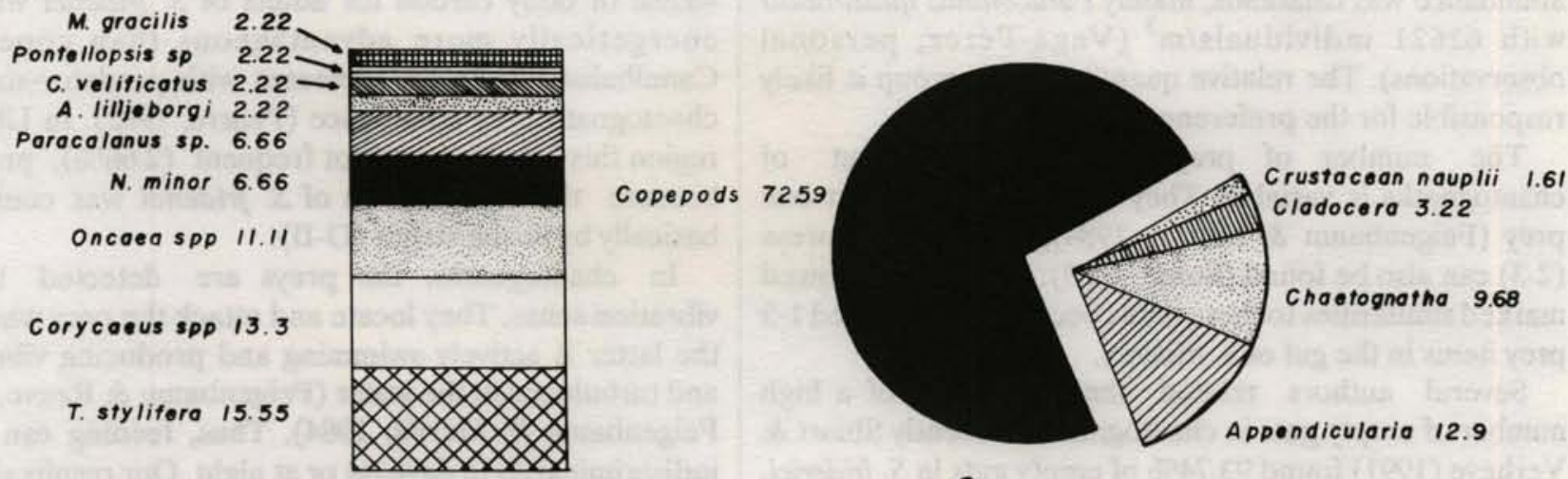

C

Fig. 3. Main food items of Sagitta friderici at different maturity stages.

(A) stage $O$, (B) stage I, (C) stage II. 


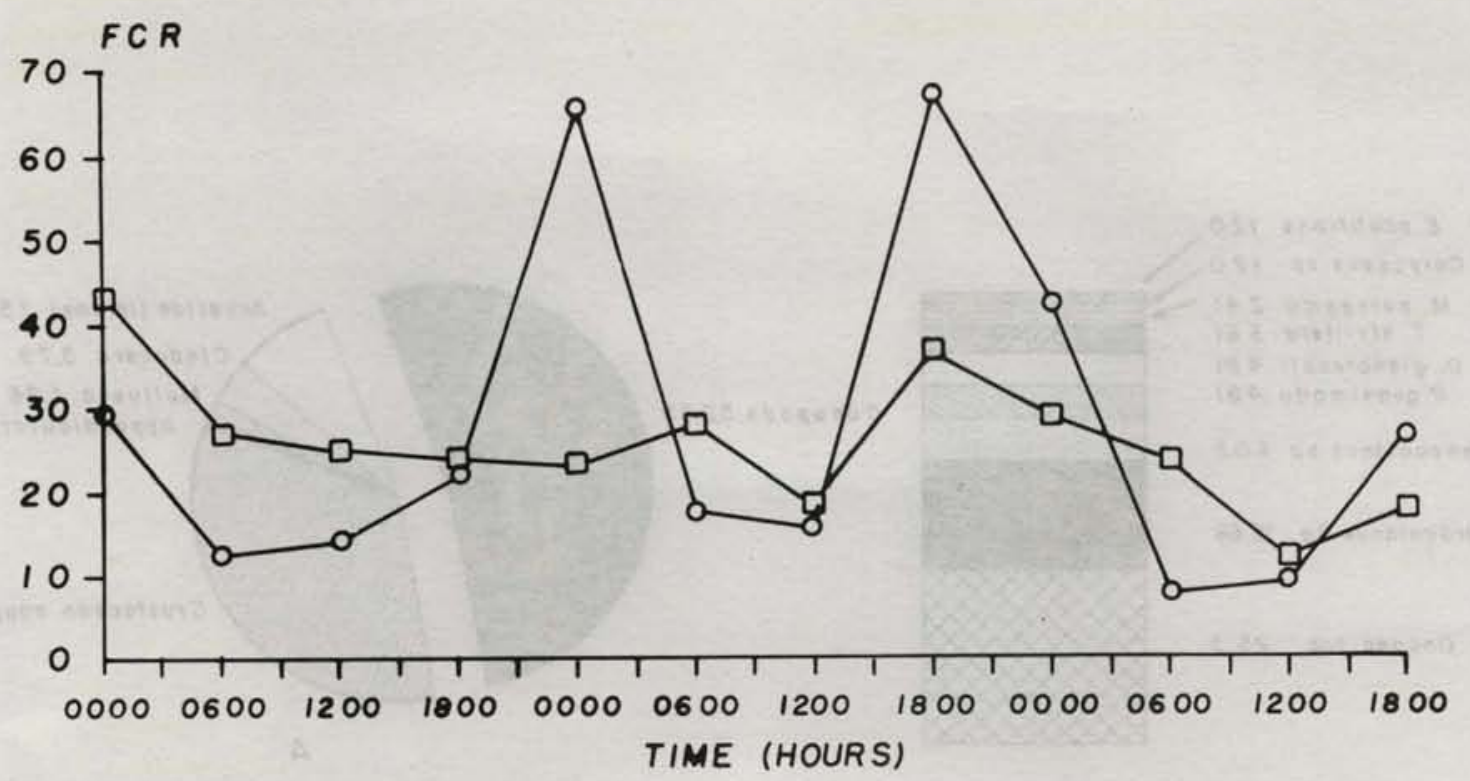

Fig. 4. Food containing ratio of Sagitta friderici collected at different times of the day. $\left(-.-0_{-. .-)}\right.$Above the thermocline, (-..- $\square$-..-) Below the thermocline.

(1976). They related that calanoid and cyclopoid copepods were the preferencial food of $S$. friderici from the Agulhas Current and the Spanish Mediterranean coast.

The food taken by chaetognaths is closely related to the abundance and specific composition of the copepod in the plankton (Rakusa-Suszczewski, 1969). S. friderici can be an opportunistic predator consuming whatever the type of the prey available. Thus the large consumption of copepods would be a response to the great avaibility of this food in the environment. In the zooplankton of Ubatuba region, the dominant group in both species number and abundance was calanoids, mainly Paracalanus quasimodo with 61621 individuals $/ \mathrm{m}^{3}$ (Vega-Pérez, personal observations). The relative quantity of this group is likely responsible for the preference of $S$. friderici.

The number of prey present in the gut of chaetognaths is variable. They contain tipically just one prey (Feigenbaum \& Marris, 1984), but multiple preys (2-3) can also be found (Stone, 1969). Our results showed marked similarities to these data, because we observed 1-3 prey items in the gut of $S$. friderici.

Several authors related the presence of a high number of empty guts in chaetognaths. Recently Stuart \& Verheye (1991) found $93.74 \%$ of empty guts in S. friderici, whereas we found $76.06 \%$. This possibly reflects a great dependency on soft bodied preys as Annelida, which were not found. On the other hand, $S$. friderici could not be feeding at the depths where they were caught.

It has been demonstrated that the principal feature by which chaetognaths select the prey is the size. According to Pearre (1980) larger specimens and mature stages tend to select larger particles. Our results showed that, in $S$. friderici, the prey-size changed with the developmental stage. Younger stages (O-I) selected small preys, whereas older stages (II) preferred larger food items.

The copepod prey diversity found in the guts of the chaetognaths is proportional to the copepod species abundance in the environment (Sullivan, 1980). We recorded high diversity of prey in specimens collected beiow the thermocline, where copepod diversity was higher than above it.

Cannibalism is generally considered a valuable adaptative strategy in food limited environment. According to Stuart \& Verheye (1991), it may represent $46.8 \%$ of body carbon for adults of $S$. friderici which is energetically more advantageous than copepods. Cannibalistic behavior increases with predator-size and chaetognath prey abundance (Pearre, 1982). In Ubatuba region this behavior was not frequent $(2.66 \%)$, probably because the population of $S$. friderici was composed basically by young stages (O-II).

In chaetognaths, the preys are detected by the vibration sense. They locate and attack the prey whenever the latter is actively swimming and producing vibrations and turbulence in the water (Feigenbaum \& Reeve, 1977; Feigenbaum \& Marris, 1984). Thus, feeding can occur indiscriminately in daylight or at night. Our results showed higher food containing ratio (FCR) in $S$. friderici collected during the night period as previously reported by Nagasawa \& Marumo (1972, 1976), Szyper (1978) and $\emptyset$ resland (1987) for $S$. nagae, S. enflata and $S$. elegans, respectively.

According to Pearre (1973) the smaller feeding by chaetognaths during the light periods can be explained as an adaptation to avoid visual predators. Feeding during daylight can increase their visibility due to undigested food 
in their guts, although chaetognaths can more easily detect their preys during the diel migratory movements.

Young stages (O-I) of $S$. friderici tend to show higher FCR than the more mature stages. This may be associated with the higher metabolism that younger and smaller organisms have in response to the growth need.

Further studies on the ecology of $S$. friderici as well as in other species are necessary due to the potential contribution of this group to the secondary production of marine ecosystems.

\section{Conclusions}

1. S. friderici in Ubatuba region showed high number of specimens with empty guts.

2. The diet was composed basically of Crustacea, Annelida, Urochordatha, Chaetognatha and Mollusca.

3. The most important prey of $S$. friderici were the copepods, specially calanoids.

4. The food diversity varied with maturity stage of $S$. friderici.

5. Higher diversity of food items were observed in specimens collected below the thermocline.

6 . In $S$. friderici prey size changed with the developmental stages.

7. In Ubatuba region, the cannibalistic behavior was not frequent.

\section{Resumo}

Espécimens de Sagitta friderici foram coletados numa estação fixa de $38 \mathrm{~m}$ de profundidade, ao largo de Ubatuba, Estado de São Paulo, em março de 1989. Arrastos verticais, acima e abaixo da termoclina, foram feitos com rede de fechamento $(50 \mathrm{~cm}$ de diâmetro de boca e malha de $0.200 \mathrm{~mm}$ ) durante três dias consecutivos e em intervalos de seis horas.

O estudo de 3175 indivíduos, nos estágios de O-IV, revelou que 2415 apresentaram o trato digestivo vazio e 760 com algum tipo de alimento. Destes últimos, 283 continham material amorfo e os 473 restantes de 1 a 3 presas. Das 488 presas identificadas, $99,74 \%$ estavam localizadas na regiāo posterior do trato digestivo e $0,26 \%$ na região anterior.

A dieta de $S$. friderici esteve constituída de Crustacea, Annelida, Urochordata, Chaetognatha e Mollusca. Dentre os Crustacea, os Copepoda foram os mais abundantes, predominando os Calanoida e Cyclopoida.

$\mathrm{O}$ estágio 0 de $S$. friderici teve preferência pelos náuplios de crustáceos, enquanto que uma maior diversificação do alimento, incluindo a prática do canibalismo, foi observada a partir do estágio I.

Nâo houve diferenças significativas na composiçāo da dieta dos indivíduos coletados nos diferentes períodos do dia.

Os espécimens de $S$. friderici coletados acima da termoclina apresentaram maior porcentagem de tratos digestivos (FCR) contendo alimento.

\section{Acknowledgements}

The authors are grateful to the two anonymous referees for their criticism of the manuscript. Financial support for this investigation came from the Comissão Interministerial para os Recursos do Mar (CIRM). The junior author received the scholarship of the Coordenadoria de Aperfeiçoamento de Pessoal de Ensino Superior (CAPES) for this study.

\section{References}

ALMEIDA-PRADO, M. S. 1961. Distribuição dos Chaetognatha no Atlântico Sul Ocidental. Bolm Inst. oceanogr., S Paulo, 11(4):15-49.

1968. Distribution and annual occurrence of Chaetognatha off Cananéia and Santos coast (São Paulo, Brazil). Bolm Inst. oceanogr., S Paulo, 17(1):33-55.

ALVARIÑO, A. 1985. Predation in the plankton realm; mainly with reference to fish larvae. Inv. mar. CICIMAR, 2(n² esp. 1):1-122.

BJöRNBERG, T. K. S. 1981. Copepoda. In: Boltovskoy, D., ed. Atlas del Atlantico Sudoccidental y métodos de trabajo con el zooplancton marino. Mar del Plata, INIDEP. $936 \mathrm{p}$.

FEIGENBAUM, D. L. \& MARRIS, R. C. 1984. Feeding in the Chaetognatha. In: Barnes, M., ed. Oceanogr. mar. Biol. a. Rev., 22:343-392.

\& REEVE. M. R. 1977. Prey detection in the Chaetognatha: response to a vibrating probe and experimental determination of attack distance in large aquaria. Limnol. Oceanogr., 22(6):1052-1058.

FURNESTIN, M. L. 1957. Chaetognathes et zooplancton du secteur atlantique marrocain. Revue Trav. Inst. Pêches marit., 21(1/2):1-356. 
HEYDORN, A. E. F. 1959. The Chaetognatha off the west coast of the Union South Africa. Investl Rept Div, Sea Fish., Repub. S. Afr., 36:1-56.

McLELLAND, J. A. 1980. Notes on the northern Gulf of Mexico occurrence of Sagitta friderici Ritter-Zahony (Chaetognatha). Gulf Res. Repts, 6(4):343-348.

1989. An illustrated key to the Chaetognatha of the northern Gulf of Mexico with notes on their distribution. Gulf. Res. Repts, 8:145-172.

NAGASAWA, S. \& MARUMO, R. 1972. Feeding of a pelagic chaetognath Sagitta nagae Alvariño in Suruga Bay, Central Japan. J. oceanogr. Soc. Japan, 28(5):181-186.

$\&$

1976. Further studies on the feeding habits of Sagitta nagae Alvariño in Suruga Bay, Central Japan. J. oceanogr. Soc. Japan, 32(5):209-218.

ØRESLAND, V. 1987. Feeding of the chaetognaths Sagitta elegans and S. setosa at different seasons in Gullmarsfjorden, Sweden. Mar. Ecol.-Prog. Ser., 39:69-79.

PEARRE Jr., S. 1973. Vertical migration and feeding in Sagitta elegans Verril. Ecology, 54:300-314.

1976. A seasonal study of the diets of three sympatric chaetognaths. Investigacion pesq., Barcelona, 40(1):1-16.

1980. Feeding by Chaetognatha: the relation of prey size to predator size in several species. Mar. Ecol.- Prog. Ser., 3:125-134.

1982. Feeding by Chaetognatha: aspects of inter- and intra-specific predation. Mar. Ecol.-Prog. Ser., 7:33-45.
RAKUSA-SUSZCZEWSKI, S. 1969. The food and feeding habits of Chaetognatha in the seas around the British Isles. Pol. Archs Hydrobiol., 16:213-232.

REEVE, M. R. 1970. The biology of Chaetognatha I. Quantitative aspects of growth and egg production in Sagitta hispida. In: Steele, J. H., ed. Marine food chains. Edinburgh, Oliver \& Boyd. p. 168-189.

\& WALTER, M. A. 1972. Conditions of culture, food-size selection, and the effects of temperature and salinity on growth rate and generation time in Sagitta hispida Conant. J. expl mar. Biol. Ecol., 9:191-200.

STONE, J. H. 1969. The chaetognatha community of the Agulhas Current: its structure and related properties. Ecol. Monogr., 39(4):433-463.

STUART, V. \& VERHEYE, H. M. 1991. Diel migration and feeding patterns of the chaetognath, Sagitta friderici, off the west coast of South Africa. J. mar. Res., 49:493-515.

SULLIVAN, B. K. 1980. In situ feeding behaviour of Sagitta elegans and Eukrohnia hamata (Chaetognatha) in relation to the vertical distribution and abundance of prey at Ocean Station "P". Limnol. Oceanogr., 25(2):317-326.

SZYPER, J. P. 1978. Feeding rate of the chaetognath Sagitta enflata in nature. Estuar. coast. mar. Sci., 7:567-575.

(Manuscript received 16 June 1992; revised 23 November 1992; accepted 10 December 1992) 